\title{
ANALISIS KERUSAKAN EKOSISTEM MANGROVE TERHADAP PENDAPATAN MASYARAKAT PESISIR DI DESA TONGKE-TONGKE KECAMATAN SINJAI TIMUR KABUPATEN SINJAI
}

\section{Analysis of Mangrove Ecosystem Damage to Coastal Community Income in Tongke-Tongke Village, Sinjai Timur District, Sinjai Regency}

\author{
Ikbal $^{1}$, Andi Gusti Tantu ${ }^{2}$, Suryawati Salam ${ }^{2}$ \\ ${ }^{1}$ Dinas Perikanan dan Kelautan Kabupaten Sinjai, Sulawesi Selatan \\ ${ }^{2}$ Fakultas Pertanian, Universitas Bosowa Makassar \\ E-mail: ikbaldata@gmail.com
}

Diterima 10 Maret 2019

Dipublikasi 02 Mei 2019

\begin{abstract}
ABSTRAK
Penelitian dilaksanakan bulan Januari sampai dengan Maret 2016 di Desa Tongke-tongke Kecamatan Sinjai Timur Kabupaten Sinjai. Metode yang digunakan adalah metode quisionering dilakukan dengan random sampling. Analisa data dilakukan secara deskriptif dan Paired Sample T-test untuk mengetahui signifikasi perbedaan beberapa indikator yang dianalisis pada saat sebulum dan sesudah terjadinya kerusakan ekosistem mangrove. Hasil penelitian menunjukan bahwa Pendapatan masyarakat pantai sebelum dan sesudah kerusakan ekosistem mangrove di lokasi penelitian di dapatkan perbedaan yang signifikan. Tingkat saving masyarakat nelayan relative rendah, yakni hanya sebesar rata-rata empat koma enam puluh lima persen dari total pendapatan keluarga sehingga potensi pengembangan perekonomian wilayah melalui peningkatan investasi lokal juga relative rendah. Terdapat perbedaan yang signifikan antara keragaman jenis tangkapan nelayan antara sebelum dan sesudah terjadinya kerusakan hutan mangrove dimana berbagai jenis biota laut tangkapan nelayan menjadi hilang dan/atau semakin langka sesudah terjadinya kerusakan ekosistem hutan mangrove. Kerusakan ekosistem hutan mangrove berpengaruh terhadap kesempatan kerja masyarakat nelayan yang disebabkan berkurangnya bahan baku, benih untuk budidaya serta berkurangnya potensi tangkapan nelayan sekitar lokasi penelitian.
\end{abstract}

Kata Kunci: Ekosistem Mangrove, Pendapatan Masyarakat, Pesisir, Tongke, Sinjai

\begin{abstract}
The research was conducted from January to March 2016 in the village of Tongke-tongke Eastern SinjaiSinjai district. The method used is a method quisionering done by random sampling. The data were analyzed descriptively and Paired Sample T-test to determine the significance of differences in some of the indicators that are analyzed at the time sebulum and after the occurrence of damage to mangrove ecosystems. The results showed that the income of coastal communities before and after the destruction of mangrove ecosystems in the study site in getting significant difference. Saving the fishing community level is relatively low, which only amounted to an average of four point sixty five percent of the total family income so that the potential of regional economic development through increased local investment is also relatively low. There are significant differences between the species diversity of fishermen between before and after the occurrence of damage to mangrove forests where many kinds of marine fishermen became lost and / or increasingly scarce after the destruction of mangrove forest ecosystems. Damage to the mangrove forest ecosystem affect the employment opportunities of fishing communities resulting reduction in raw materials, seeds for cultivation as well as decrease the potential for fishermen catch around the study site.
\end{abstract}

Keywords: Mangrove Ecosystem, Revenue community, Coastal,

\section{PENDAHULUAN}

Indonesia merupakan salahsatu negara di dunia dalam bentuk negara kepulauan. Selain itu, Indonesia memiliki sumberdaya laut dan pesisir yang melimpah di seluruh wilayah sekitar garis pantai Indonesia, baik hayati maupun non hayati. Salah satu sumberdaya laut dan pesisir yang terdapat di
Indonesia adalah ekosistem hutan mangrove yang berada hampir di setiap wilayah pesisir dan garis pantai Indonesia. Mangrove merupakan formasiformasi tumbuhan pantai yang khas di sepanjang pantai tropis dan sub tropis. Salah satu ekosistem yang unik, hutan mangrove merupakan sumber daya alam potensial, karena mempunyai tiga fungsi pokok, yaitu fungsi ekologis; sebagai daerah asuhan nursery 
ground), dan pemijahan (spawning ground), mencari makan (feeding ground) beberapa organisme (Dahuri, 2001; Budi et al, 2018; Budi et al, 2016),

Ekosistem Mangrove di desaTongke - tongke memiliki tingkat kepadatan yang tinggi. Kondisi ini memberi pengaruh yang dominan terhadap siklus ekologi pada wilayah itu. Namun fakta yang memperlihatkan bahwa kondisi mangrove pada daerah itu cukup mengkhawatirkan, hal ini disebabkan karena terjadinya konversi lahan pada beberapa tempat untuk keperluan tambak, serta kurangnya rehabilitasi yangdilakukan oleh masyarakat ataupun pemerintah. Untuk ekosistem hutan mangrove yang mengalami kerusakan disebabkan oleh aktivitas ekonomi penduduk perlu dilakukan upaya pelestarian ekosistem hutan mangrove oleh pemerintah dan masyarakat dengan konservasi, reboisasi, dan rehabilitasi hutan mangrove. Upaya pelestarian ekosistem hutan mangrove yang dilakukan oleh pemerintah biasanya dilakukan oleh Departemen Kehutanan, Departemen Kelautan dan Perikanan maupun dari Pemerintah daerah setempat kemudian dibantu oleh masyarakat yang ikut berpartisipasi dalam menjaga kelestarian lingkungan alam

\section{METODE PENELITIAN}

Penelitian ini dilaksanakan mulai dari bulan September - November 2018 diperairan Sinjai Timur, Kabupaten Sinjai, Sulawesi Selatan.

Tabel 1. Jumlah Kepala Keluarga populasi dan Sampel Penelitian

\begin{tabular}{|l|l|l|l|l|}
\hline \multirow{2}{*}{ No } & \multicolumn{2}{|c|}{ Jumlah KK Populasi } & \multicolumn{2}{c|}{ JumlahResponden } \\
\cline { 2 - 5 } & JenisPekerjaan & Jum & JenisPekerjaan & Jum \\
\hline 1 & Nelayan & 168 & Nelayan & 42 \\
\hline 2 & Pedagang & 28 & Pedagang & 7 \\
\hline 3 & Pembudidaya & 48 & Pembudidaya & 12 \\
\hline 4 & Pembuatarang & 20 & Pembuatarang & 5 \\
\hline 5 & PengumpulKayu & 20 & PengumpulKayu & 5 \\
\hline 6 & PemgolahIkan & 16 & PemgolahIkan & 4 \\
\hline & Jumlah & 300 & & 75 \\
\hline
\end{tabular}

Teknik pemilihan responden pada metode Quisionering dilakukan dengan random sampling dimana responden dipilih secara acak. Data yang diperoleh berupa tingkat pendapatan, keragaman jenis tanggapan, kemudahan bekerja dan berusaha serta ketersediaan bahan baku dan komoditas perdagangan sebelum dan sesudah terjadinya kerusakan ekosistem mangrove dan akan diuji dengan menggunakanPaired sample T-test, yaitu uji statistic untuk menetukan signifikasi perbedaan dua populasi data yang saling berhubungan. Pengujian dilakukan dengan menggunakan criteria Uji :

- Jika nilai $\mathrm{t}_{\text {hitung }} \leq \mathrm{Nilai}_{\mathrm{tabel}}$, maka $\mathrm{H}_{0}$ tidak ditolak, sehingga ${ }^{\wedge} \mu \mathrm{p} 1={ }^{\wedge} \mu \mathrm{p} 0$ yang berarti bahwa pendapatan, keragaman jenis tangkapan, kemudahan bekerja dan berusaha serta ketersediaan bahan baku dan komoditas perdagangan sesudah terjadinya kerusakan tidak berbeda nyata dengan sebelum terjadinya kerusakan ekosistem mangrove.

- Jika nilai $t_{\text {hitung }}>$ Nilai $t_{\text {tabel }}$, maka $\mathrm{H}_{\mathrm{o}}$ ditolak (terima $\mathrm{H}_{1}$ ) sehingga ${ }^{\wedge} \mu \mathrm{p} 1 \neq{ }^{\wedge} \mu \mathrm{p} 0$ yang berarti bahwa pendapatan, keragaman jenis tangkapan, kemudahan bekerja dan berusaha serta ketersediaan bahan baku dan komoditas perdagangan sesudah terjadinya kerusakan tidak berbeda nyata dengan sebelum terjadinya kerusakan ekosistem mangrove.

Jumlah responden yang diambil sebanyak $25 \%$ (Suharsini, 1991) dari sekitar 300 orang penduduk desa atau 75 orang responden untuk mendapatkan jumlah sampel yang layak pada masing-masing kelompok responden. Responden diusahakan sejauh mungkin mewakili kelompok aktivitas ekonomi masyarakat nelayan yang terkait dengan kegiatan perikanan, seperti penangkapan, budidaya, pengolahan dan perdagangan.

\section{HASIL DAN PEMBAHASAN}

\section{Keragaman Jenis dan Jumlah Hasil Tangkapan}

Kerusakan ekosistem hutan mangrove yang terjadi selama kurung waktu 10 tahun terakhir telah mengakibatkan penurunan jenis biota laut hasil tangkapan nelayan secara signifikan. Berdasarkan data jenis-jenis ikan yang mengalami kondisi tidak pernah lagi atau sudah semakin jarang ditemukan kesemuanya merupakan jenis-jenis ikan pelagis kecil dan demersal yang sepanjang dan sebagian daur hidupnya sangat bergantung kepada eksistensi ekosistem hutan mangrove. Misalnya jenis-jenis kepiting, kerapu, udang tiger, kakap, pari, cumicumi, tenggiri.Dalam satu rantai makanan pada sebuah habitat tertentu keberadaan salah satu unsur penyeimbang akan mempengaruhi keberadaan sweluruh tangga rantai makanan. Hal yang sama terjadi di kawasan ekosistem hutan mangrove di Desa tongke-tongke dimana berkurangnya substrak biomassa hutan bakau berpengaruh terhadap keragaman dan jumlah biota laut pada seluruh tangga rantai makanan.

\section{PendapatanNelayan}

Kegiatan penangkapan ikan dilaut merupakan aktivitas ekonomi utama dari keluarga nelayan, termasuk dilokasi penelitian. Oleh karena itu penurunan jenis dan jumlah biota laut hasil tangkapan nelayan secara langsung berakibat pada menurunnya pendapatan rumah tangga nelayan di lokasi penelitian.Berdasarkan data hasil penelitian, terjadi perbedaan secara signifikan pada taraf nyata 95\% antara pendapatan riil nelayan sebelum dan sesudah terjadinya kerusakan ekosistem hutan mangrove. Tingginya penurunan relatif pada kelompok ini di karenakan komodii utama budidaya laut dilokasi penelitian adalah ikan kerapu dan kepiting bakau, dimana keduanya memiliki habitat hutan mangrove pada sebagian besar dan seluruh daur hidupnya sehingga kerusakan ekosistem hutan 
bakau berakibat langsung terhadap ketersediaan benih untuk budidaya laut. Berkurangnya spesiesspesies biota laut tangkapan nelayan ini juga berdampak langsung terhadap sebagian besar masyarakat pantai, yaitu mereka yang berpenghasilan utama dari penangkapan ikan di laut.

\section{Kesempatan Berusaha}

Setelah terjadinya kerusakan ekosistem, masyarakat pantai menyatakan bahwa kesempatan berusaha menjadi lebih sedikit dibandingkan kondisi sebelum terjadinya kerusakan. Kegiatan berusaha yang dimaksudkan di sini adalah kegiatan usaha nelayan yang umumnya berbasis pemanfaatan sumberdaya perikanan dan usaha pendukung kebutuhan sehari-hari nelayan, seperti budidaya laut, perdagangan hasil laut, pengolahan hasil laut, suplai kebutuhan melaut dan kebutuhan harian rumah tangga, jasa pembuatan alat penangkapan dan lainlain.

\section{Kesempatan Kerja}

Sama halnya dengan kasus kesempatan berusaha masyarakat pantai juga menyatakan adanya perbedaan yang signifikan pada taraf nyata $95 \%$ antara kesempatan kerja yang tersedia sebelum terjadinya kerusakan dengan sesudah terjadi kerusakan. Kesempatan kerja yang dimaksudkan di sini adalah kesempatan kerja di lokasi penelitian yang terkait dengan pemanfaatan sumber daya alam pesisir dan laut beserta aktivitas pendukung kehidupan yang ada.

Berkurangnya hasil tangkapan juga berakibat pada berkurangnya volume aktivitas ekonomi di lokasi penelitian yang secara langsung berakibat pada menurunnya kebutuhan tenaga kerja yang diperlukan. Berkurangnya hasil tangkapan berupa jenis-jenis ikan yang bisa dibudidayakan menyebabkan berkurangnya pelaku usaha dan volume usaha budidaya yang berakibat pada berkurangnya tenaga kerja langsung maupun tidak langsung yang terlibat.

\section{KESIMPULAN DAN SARAN}

Berdasarkan hasil penelitian ini dapat disimpulkan bahwa tingkat saving masyarakat nelayan relative rendah, yakni hanya sebesar rata-rata empat koma enam puluh lima persen dari total pendapatan keluarga sehingga potensi pengembangan perekonomian wilayah melalui peningkatan investasi lokal juga relative rendah. Terdapat perbedaan yang signifikan antara keragaman jenis tangkapan nelayan antara sebelum dan sesudah terjadinya kerusakan hutan mangrove dimana berbagai jenis biota laut tangkapan nelayan menjadi hilang dan/atau semakin langka sesudah terjadinya kerusakan ekosistem hutan mangrove. Kerusakan ekosistem hutan mangrove berpengaruh terhadap kesempatan kerja masyarakat nelayan yang disebabkan berkurangnya bahan baku, benih untuk budidaya serta berkurangnya potensi tangkapan nelayan sekitar lokasi penelitian

\section{DAFTAR PUSTAKA}

Anonimous. 2001. Pedoman Umum Pemberdayaan Ekonomi Masyarakat Pesisir. Direktorat Jenderal Pesisir dan Pulau-Pulau Kecil. DKP RI, Jakarta

Anonimous. 1997. Strategi Nasional Pengelolaan Kawasan Mangrove di Indonesia.Jakarta

Arief, A., 2003. Hutan Mangrove Fungsi dan Manfaatnya. Kanisius, Jakarta.

Anggadireja, J.T, Zatnika A, Istini, S., 2006. Rumput Laut. Swadaya.Jakarta.

Badan Pusat Statistik, 2010. Kabupaten Sinjai dalam Angka, Sinjai Sulawesi selatan.

Budi, S., Karim, M. Y., Trijuno, D. D., Nessa, M. N., Gunarto, G., \& Herlinah, H. (2016). The use of fatty acid omega-3 HUFA and Ecdyson Hormone To Improve Of Larval Stage Indeks and Survival Rate Of Mud Crab Scylla olivacea. Simposium Nasional Kelautan dan Perikanan, 3, 487-498.

Budi, S., Karim, M. Y., Trijuno, D. D., Nessa, M. N., Gunarto, G., \& Herlinah, H. (2016, August). Tingkat Dan Penyebab Mortalitas Larva Kepiting Bakau, Scylla spp. Di unit Pembenihan Kepiting Marana Kabupaten Maros. In Prosiding Forum Inovasi Teknologi Akuakultur (Vol. 1, No. 1, pp. 465-471).

Budi, S., Karim, M. Y., Trijuno, D. D., Nessa, M. N., \& Herlinah, H. (2018). Pengaruh Hormon Ecdyson Terhadap Sintasan Dan Periode Moulting Pada Larva Kepiting Bakau Scylla olivacea. Jurnal Riset Akuakultur, 12(4), 335339.

Effendy, H., 2003. Telaah Kualitas Air.Kanisisus.Yogyakarta

Freile-pelegrin Y, Robledo D, Azamar J.A. 2006. Carageenan of Eucheuma isiforme conditions. Botanica Marina 49 (1):65-71. DOL: 10.1515/BOT.2006.009.

(FAO) Food Agricultural Organization. 2007. Compendium of Food Additive Spesificaton. Rome: Communication Division FAO Viale delle Terme di Caracalla.

Kadi, A. 2004. Budidaya Rumput Laut Kappaphycus Alvarezi dan pengembangannya Nusa Penida. Oseana. Vol.XXIX, No. 4. Hlm. 25-36.

Kune, S. 2000. Studi Pertumbuhan Enhalus Sp dan Eucheuma Sp dalam Upaya pengelolaan secara terpadu di pulau Tanakeke.

Mtolera, M. S. P. 2003. Effect of Seagraas Cover and Mineral Content of Kappaphycus and Eucheuma Prodectivity in Zanzibar. Wstern Indian Ocean J. Mar. Sci. Vol. 2 (2): 163-170.

Mubarak, H., dan I.S. Wahyuni dalam Mala. 2015. Petunjuk Teknis Budidaya Rumput Laut. Pusat Penelitian dan Pengembangan Pertanian. Puslitbangkan. Jakarta IDRC-INFIS. 34 hal.

Munoz, J, Y. Freile-Pelegin and D. Robledo. 2004. Marculture Of Kappaphycus Alvarezi ( Rodophyta, Solieriaceae) Color Strains in 
Tropical Waters of Yucatan, Mexico. Aquaculture, 239: 161-177.

Nurjanah. 2003. Prospek Pemanfaatan Rumput Laut. Seminar Diversifikasi Rumput Laut. Makalah pada Seminar Rumput Laut tanggal 3 Mei 2003. Fakultas Perikanan dan IlmuKelautan, Institut Pertanian Bogor, Bogor.

Patadjai, R.S 2007. Pertumbuhan, Produksi dan Kualitas Rumput Laut Kappaphycus Alvarezi (Doty) pada Berbagai Habitat Budidaya yang Berbeda di Sertasi. Program Pascasarjana UNHAS. Makassar.

Richohermoso, M.A, P.B. Bueno, \& V.T. Sulit. 2007. Maxximizing Opportunities in Seaweeds Farming. MCPI/NACA/SEAFDEC. 8 pp. 